\title{
ANALYSIS AND RESEARCH ON CHINA MONGOLIAN TRADE COMPETITION AND COMPLEMENTARITY
}

\author{
Ph.D. student Mavidkhaan Baasandulam \\ People's Republic of China, Hunan province, Xiangtan city, School of Business, Hunan University of \\ Science and Technology
}

DOI: https://doi.org/10.31435/rsglobal_ijite/30112019/6796

\section{ARTICLE INFO \\ Received 20 September 2019 \\ Accepted 09 November 2019 \\ Published 30 November 2019}

\section{KEYWORDS}

Natural resources,

Trade complementarity,

World market,

Comparative advantage. \begin{abstract}
The development of trade between China and Mongolia should be based on complementary product trade. On this basis, products with trade potential should be continuously explored to expand the scale and structure of ChinaMongolian trade and promote the continuous development of bilateral trade. This paper analyzes the current situation of economic and trade cooperation and trade complementarity between China and Mongolia, and concludes that China and Mongolia have different comparative advantages in export products. Mongolia's export is highly integrated with China's trade, and the two countries are highly complementary in trade.
\end{abstract}

Citation: Mavidkhaan Baasandulam. (2019) Analysis and Research on China Mongolian Trade Competition and Complementarity. International Journal of Innovative Technologies in Economy. 6(26). doi: 10.31435/rsglobal_ijite/30112019/6796

Copyright: (C) 2019 Mavidkhaan Baasandulam. This is an open-access article distributed under the terms of the Creative Commons Attribution License (CC BY). The use, distribution or reproduction in other forums is permitted, provided the original author(s) or licensor are credited and that the original publication in this journal is cited, in accordance with accepted academic practice. No use, distribution or reproduction is permitted which does not comply with these terms.

Introduction. Mongolia has abundant natural resources and great potential market. It is the source of mineral resources and an important industrial product market in China. China-Mongolia economic and trade cooperation has been stable year by year with frequent diplomatic exchanges. As a close cooperative partner, Mongolia is a major component of China's westward and northward promotion of the "One Belt and One Road" initiative. Generally speaking, Mongolia is the first country to share the dividends of the implementation of the One Belt and One Road initiative. Therefore, the implementation of the One Belt and One Road initiative will surely play a long-term role in strengthening regional economic cooperation between the two countries.

Trade complementarity and trade potential are particularly well studied in China and globally. Chinese scholar WANG Ling (2014) investigated the trade complementarities of China, South Korea, Japan and other Asian countries by using indicators such as revealed comparative advantage, and concluded that the trade complementarities of agricultural products between China, South Korea and Japan were relatively weak, but some agricultural products between China and Japan were highly complementary. Trade competitiveness and agricultural products are complementary between China and ACEAN, and there is a strong potential for cooperation between China and ACEAN. Jie Lv and Long Bin Xiang (2010) 's empirical analysis of China United State America trade between 2000 and 2006 shows that the comparative advantage between industry and international competitiveness can be obtained by using RCA and industry-based trade index. The trade gap between China and the United States indicates that the trade relationship between the two countries is stable. Yang Cheng Jia and He Ji Ye (2018) studied the China and the countries along the "area" bilateral trade competitive and complementary, found that China and the commonwealth of independent states (cis) region, central and eastern Europe bilateral trade relationship is loose, but China's "neighborhood" all the way along the country's export trade potential is stronger, "One Belt And One Road" along the country's exports to China trade potential weakening trend. Kabiru Hannafi Ibrahim (2015), a Nigerian scholar, used the trade integration index to analyze the trade complementarities between Nigeria and India, and found that Nigeria and India could improve the RCA 
index of other countries highly industrial product trade. Compared with other developed countries, ChinaMongolian trade cooperation is still short, its historical basis is weak, and its trade cooperation model is single. Therefore, there are few studies on trade complementarity and trade potential between China and Mongolia. Pan Yun Jiao (2016) studied the trade complementarity between China and Mongolia by using trade complementarity and other indexes to analyze the trade complementarity between the two countries, and introduced the gravity model to calculate the trade potential of the two countries. It was found that the two countries were highly complementary and the trade potential increased rapidly. These studies on trade complementarity and trade potential provide useful references for the analysis of trade complementarity and trade potential between China and Mongolia. Based on the economic and trade cooperation between China and Mongolia, this paper calculates and analyzes the data of the statistics bureau of China and Mongolia. The index analysis mainly includes the index of revealed comparative advantage, the index of trade complementarity and the index of net trade ratio.

China-Mongolia economic and trade cooperation.

Mongolia's foreign trade has become an important part of Mongolia's social and economic development and expansion. At the beginning of the transition period, Mongolia's foreign trade volume fell, reaching us $\$ 7$ million in 1991, a steady increase compared with the mid-1990s.Trade between China and Mongolia was only $\$ 1.414$ billion in 2007, but Mongolia has been working since 2010 to reform its mining industry and improve the investment environment. With the implementation of this policy, the economy has recovered and trade between the two countries has risen again. The decline of the price of mining products in the world market, the total foreign trade of Mongolia and the total trade of China and Mongolia declined in 2012-2013. However, with China and Mongolia actively promoting and coordinating the connection of "One Belt and One Road" and "Grassland Road", China-Mongolian trade has reached a new level. In 2017, Mongolia's trade with 163 countries and regions was us $\$ 10.536$ billion, up 27.3 percent over the previous year, while China and Mongolian trade was us $\$ 6.72$ billion, accounting for 63.92 percent of Mongolia's foreign trade. Among them, Mongolia's exports to China increased from us $\$ 257$ million in 2000 to us $\$ 5.30$ billion in 2017, and its imports increased from us $\$ 66$ million to us $\$ 1.42$ billion. In 2014 and 2017, the foreign trade volume between China and Mongolia in Mongolia increased to 62.1 percent and 64 percent respectively. Reflects the factors that affect the growth of trade between the two countries.

From the perspective of the trade structure between China and Mongolia, China's exports to Mongolia are mainly gasoline, clothing, textiles, industrial and mining equipment, electrical appliances, construction materials and consumer goods. Mongolia's exports to China are mainly leather, animal and plant medicine, wood, scrap metal, coal and iron ore and more than 20 products. As China's economy has growth. its demand for trees, coal and energy has grown beyond its domestic supply of resources. However, Mongolia is rich in minerals and raw materials, and trade between China and Mongolia is very active, so Mongolia can provide mineral resources for China. China and Mongolia have little overlap in export product mix and market. This indicates that China and Mongolia have weak export trade competition and incomparable complementary advantages in product structure.

\section{Analysis of trade complementarity between China and Mongolia}

In this part, Trade Integration Index, comparative advantage index and net trade ratio were used to study the trade complementarity between China and Mongolia. The research process and results are as follows:

(I) Analysis of the integration degree of China and Mongolian trade

The trade integration index (TII, 1947) was developed by economist Gordon brown. The trade integration index is widely used to measure the degree of trade interdependence between trade partners and the proportion of a country's exports to a trading partner in the country's total exports, as well as the proportion of its imports to the world's total imports. The larger the number, the closer trade links between the two countries. Its formula is:

$$
\mathrm{TII}_{\mathrm{ab}}=\frac{\left(\mathrm{x}_{\mathrm{ab}} / \mathrm{X}_{\mathrm{a}}\right)}{\left(\mathrm{M}_{\mathrm{b}} / \mathrm{M}_{\mathrm{w}}\right)},
$$

Where, $\mathrm{TII}_{\mathrm{ab}}$ is the trade integration degree of country a to country $\mathrm{b} ; \mathrm{X}_{\mathrm{ab}}$ is the export amount of country a to country $b ; X_{a}$ is the total export amount of country $a ; M_{b}$ Is the total import of country $b ; M_{w}$ Is the world's total import; If TII is greater than 1, the two countries have close trade cooperation. If TII is less than 1 , the trade cooperation between the two countries is loose. 
Table 2 shows that Mongolia's trade integration degree with China between 2000 and 2017 was 7.6. China's trade integration with Mongolia is 2.02. Degree of trade interdependence is greater than 1, which means that China and Mongolia are closely linked in trade. Mongolia's trade integration with China is relatively high, which means Mongolia's economic dependence on China is high. In addition, from the overall trade integration degree, China's trade integration degree with Mongolia has a downward trend, Mongolia's trade integration with China is not so stable, and the degree of trade integration in the last three or four years also has a downward trend.

Table 1. Trade Integration Index of China and Mongolia

\begin{tabular}{c|ccccc} 
Year & $T I_{C M}$ & $T I I_{M C}$ & Year & $T I_{C M}$ & $T I I_{M C}$ \\
\hline 2000 & 4.66 & 16.2 & 2009 & 5.19 & 9.23 \\
2001 & 4.68 & 13.22 & 2010 & 4.38 & 9.4 \\
2002 & 4.05 & 12.22 & 2011 & 3.99 & 9.7 \\
2003 & 3.39 & 8.53 & 2012 & 3.4 & 9.25 \\
2004 & 3.57 & 7.92 & 2013 & 3.5 & 8.68 \\
2005 & 2.46 & 7.69 & 2014 & 3.37 & 8.78 \\
2006 & 3.73 & 10.47 & 2015 & 2.87 & 8.3 \\
2007 & 3.74 & 10.43 & 2016 & 2.25 & 8.5 \\
2008 & 3.17 & 9.22 & 2017 & 2.02 & 7.6
\end{tabular}

Data source: Calculated according to statistics of Mongolia and China

(II) Analysis of Trade Comparative Advantage Index

American economist Bela Balassa proposed the trade explicit comparative advantage index (RCA, 1965), which is a tool used to test trade-related comparative advantage. It represents the overall proportion of a country's total exports and exports of a certain type of product in its trade scale, as well as the relative proportion of such products in its trade in the total trade scale worldwide. In this part, SITC Rev4.0 is adopted to classify the products traded between China and Mongolia into 10 categories. Category0 is food and live animal products; 1 is beverages and tobacco; 2 types of nonedible raw materials; The three categories are fossil fuels and lubricants and raw materials; Four are animal fats; Five are chemicals; 6 categories are manufactured goods classified by raw materials; Category 7 is machinery and transportation equipment; 8 for miscellaneous products; 9 categories are unclassified products. Among them, 0-4 are primary products, 5 and 7 are technology and capitalintensive products, and 6 and 8 are labor-intensive products.

RCA is greater than 2.5 , which means a country has a strong competitiveness in the market. RCA is greater than 1.25 and less than 2.5 , indicating that such products of a country have very strong competitiveness in the international market. RCA is between 1.25 and 0.8 , and it believes that a country's such products are relatively competitive in the international market. RCA is less than 0.8 , indicating that a country has a relative disadvantage in the international market.

According to Balassa's point of view, if the export RCA of the same type of products of both countries is greater than 1, it means that the trade of such products between the two countries is competitive. If the export RCA of one country is greater than 1 and the export RCA of the other country is less than 1, it indicates that the trade of such products between the two countries is complementary. If both countries export RCA of the same type of products are less than 1, it means that both countries have a comparative disadvantage in the trade of such products. Its formula is:

$$
\mathrm{RCA}=\frac{\mathrm{x}_{\mathrm{a}}^{\mathrm{i}} / \mathrm{x}_{\mathrm{a}}}{\mathrm{x}_{\mathrm{w}}^{\mathrm{i}} / \mathrm{X}_{\mathrm{w}}}
$$

In the formula, $\mathrm{X}_{\mathrm{a}}^{\mathrm{i}}$ is the export volume of category I product of country $\mathrm{a}, \mathrm{X}_{\mathrm{a}}$ is the total export volume of all products of country $\mathrm{a}, \mathrm{X}_{\mathrm{W}}^{\mathrm{i}}$ is the export volume of category I products of all countries in the world, $\mathrm{X}_{\mathrm{W}}$ is the total export volume of all countries in the world.

China as an exporter of dominant comparative advantage index, starting in 2000, China's SITC7 (machinery and transport equipment), revealed comparative advantage index has more than 1 , show that the comparative advantage of China's manufacturing sector has been increasing, capital and technology products are with strong international competitiveness, which is consistent with China's status as a manufacturing power, are also associated with China's role as the world's factory. In recent years, as a representative of China's high-end equipment manufacturing industry. According to statistics, China has 
negotiated with 30 countries to introduce high-speed rail technology or cooperate in development, which proves the outstanding achievements of China's manufacturing industry. RCA index, according to China's relatively weak primary product competitiveness, and downward trend year by year, including SITC0 (Food and live animal products), SITC1 (Beverages and tobacco), SITC2 (Non-food raw materials), SITC3 (Fossil fuel and lubricating oil and raw materials), SITC4 (Animal fats), the reason is that China is the world's most populous country, population densities, nature resources consumption is big, so there is no comparison between the advantage of resources intensive products. However, China has obvious advantages in labor-intensive products, including SITC6 (Finished products by raw materials) and SITC8 (Miscellaneous products). In particular, SITC8 products have a strong international competitiveness of more than 2, but SITC6 (Finished products by raw materials) has shown an overall decline since 2000. In short, China's comparative advantage in capital expenditure or technology-intensive products is gradually growing, and the comparative advantage in labor-intensive products is obvious and will continue to be, but China is not competitive in resource-intensive products. This shows that China is rich in labor resources and relatively lacking in natural resources and capital factors.

Mongolia as an exporter of dominant comparative advantage index, the primary products (SITC04) : In addition to (SITC2) Non-food raw materials, SITC0, SITC1, SITC3, SITC4 products the RCA index of less than 1, and SITC2 products of RCA index greater than 7, the Mongolia in food and live animals products, drink and smoke, fossil fuel and lubricating oil and raw materials and animal oils and fats products exports have disadvantages, such as non-edible strong comparative advantage on the lead product export. Technology and capital intensive products (SITC5, 7): the RCA index for SITC5 chemicals is less than 0.8 , indicating a disadvantage in the export of the product. The RCA index of SITC7 for machinery and transportation equipment maintained a trend of more than 1 from 2003 to 2013, indicating that Mongolia has a relatively competitive position in the export of SITC7 products. The RCA index of SITC9 unclassified products is all greater than 1, especially, some years are more than 2.5 , so it can be calculated that Mongolia has a strong comparative advantage in the export of unclassified products.

Table 2 Comparative Advantage Index of China as an exporter

\begin{tabular}{c|llllllllll} 
Year & SITC & SITC 1 & SITC 2 & SITC 3 & SITC 4 & SITC 5 & SITC 6 & SITC 7 & SITC 8 & SITC 9 \\
\hline 2000 & 0.979 & 0.150 & 0.440 & 0.157 & 0.008 & 0.482 & 1.700 & 1.140 & 1.730 & 0.015 \\
2001 & 0.796 & 0.165 & 0.514 & 0.320 & 0.042 & 0.250 & 1.650 & 1.230 & 1.640 & 0.037 \\
2002 & 0.749 & 0.336 & 0.450 & 0.287 & 0.100 & 0.470 & 1.625 & 1.320 & 3.100 & 0.046 \\
2003 & 0.670 & 0.254 & 0.384 & 0.281 & 0.057 & 0.445 & 1.575 & 1.420 & 2.880 & 0.068 \\
2004 & 0.858 & 0.506 & 0.330 & 0.243 & 0.042 & 0.443 & 1.696 & 2.260 & 2.640 & 0.046 \\
2005 & 0.589 & 0.181 & 0.324 & 0.193 & 0.088 & 0.468 & 1.695 & 1.540 & 2.550 & 0.070 \\
2006 & 0.530 & 0.162 & 0.268 & 0.153 & 0.103 & 0.459 & 1.804 & 1.570 & 2.410 & 0.079 \\
2007 & 0.504 & 0.152 & 0.249 & 0.136 & 0.062 & 0.495 & 1.804 & 1.580 & 2.440 & 0.057 \\
2008 & 0.458 & 0.150 & 0.264 & 0.138 & 0.071 & 0.560 & 1.830 & 1.570 & 2.310 & 0.030 \\
2009 & 0.453 & 0.167 & 0.224 & 0.131 & 0.051 & 0.516 & 1.540 & 1.640 & 2.490 & 0.024 \\
2010 & 0.521 & 0.172 & 0.184 & 0.169 & 0.038 & 0.550 & 1.683 & 1.650 & 2.390 & 0.023 \\
2011 & 0.531 & 0.166 & 0.197 & 0.113 & 0.044 & 0.604 & 1.683 & 1.580 & 2.420 & 0.031 \\
2012 & 0.635 & 0.127 & 0.176 & 0.116 & 0.081 & 0.554 & 1.630 & 1.570 & 2.610 & 0.023 \\
2013 & 0.630 & 0.118 & 0.228 & 0.089 & 0.057 & 0.541 & 1.630 & 1.570 & 2.630 & 0.026 \\
2014 & 0.638 & 0.124 & 0.337 & 0.105 & 0.085 & 0.574 & 1.710 & 1.830 & 2.660 & 0.031 \\
2015 & 0.695 & 0.158 & 0.292 & 0.128 & 0.096 & 0.630 & 1.490 & 1.530 & 2.820 & 0.022 \\
2016 & 0.581 & 0.167 & 0.210 & 0.079 & 0.026 & 0.581 & 0.674 & 2.340 & 2.520 & 0.087 \\
2017 & 0.553 & 0.993 & 0.227 & 0.097 & 0.035 & 0.624 & 0.628 & 2.390 & 2.420 & 0.084
\end{tabular}

Data source: Calculated based on data from the China bureau of statistics.

Due to the shortage of population in Mongolia, Mongolia has an obvious disadvantage in labor-intensive products. However, the RCA index of SITC8 products in 2003-2004 was greater than 1 , so it has a competitive relationship with China according to the viewpoint of Balassa. Compared with China, Mongolia's industrial development is relatively weak and the level of scientific and technological development is relatively slow. In fact, Mongolia's economy is dependent on mining products, but relatively weak, due to the demand for reserves in the international market, Mongolia's mining products exports declined.

(3) Analysis of net trade ratio. 
Net trade ratio (NTR) is an important index to measure the profitability of import and export of the economy and trade welfare. In the theory, the profitability of an economy's exports relative to its imports can determine a country's level of welfare. Export-led trade growth lowers a country's welfare level, while import-oriented growth increases a country's welfare level. Its formula is;

$$
\mathrm{NTR}=\frac{\mathrm{X}_{\mathrm{i}}-\mathrm{M}_{\mathrm{i}}}{\mathrm{X}_{\mathrm{i}}+\mathrm{M}_{\mathrm{i}}},
$$

In the formula, NTR is the net trade ratio, $\mathrm{X}+\mathrm{M}$ is the sum of a country's exports and imports of category I products, and $\mathrm{x}-\mathrm{m}$ is the difference between exports and imports of category I products of a two country. NTR can be greater than negative 1 and less than and 1. The larger the import amount of class I products, the smaller the NTR value and the smaller the competitiveness.

Table 3. Comparative Advantage Index of Mongolia as an exporter

\begin{tabular}{c|llllllllll} 
Year & SITC 0 & SITCm1 & SITC 2 & SITC 3 & SITC 4 & SITC 5 & SITC 6 & SITC 7 & SITC 8 & SITC 9 \\
\hline 2000 & 0.287 & 0.042 & 8.220 & 0.650 & 0.500 & 0.004 & 0.360 & 0.020 & 0.780 & 2.330 \\
2001 & 0.234 & 0.033 & 7.090 & 0.430 & 0.010 & 0.060 & 0.538 & 0.344 & 0.562 & 2.157 \\
2003 & 0.468 & 0.022 & 14.102 & 0.243 & 0.020 & 0.009 & 0.704 & 0.019 & 1.559 & 5.100 \\
2004 & 0.351 & 0.021 & 14.800 & 0.288 & 0.014 & 0.010 & 0.320 & 0.012 & 1.410 & 6.091 \\
2005 & 0.231 & 0.031 & 15.690 & 0.302 & 0.032 & 0.008 & 0.323 & 0.018 & 0.880 & 8.009 \\
2006 & 0.352 & 0.039 & 19.211 & 0.327 & 0.008 & 0.009 & 0.313 & 0.030 & 0.541 & 4.522 \\
2007 & 0.288 & 0.020 & 19.910 & 0.708 & 0.009 & 0.012 & 0.252 & 0.031 & 0.123 & 2.864 \\
2008 & 0.189 & 0.022 & 15.941 & 0.711 & 0.010 & 0.129 & 0.041 & 0.040 & 0.140 & 5.210 \\
2009 & 0.356 & 0.067 & 15.380 & 1.751 & 0.001 & 0.001 & 0.040 & 0.040 & 0.090 & 2.870 \\
2010 & 0.360 & 0.190 & 12.610 & 2.580 & 0.001 & 0.001 & 0.020 & 0.020 & 0.090 & 1.710 \\
2011 & 0.110 & 0.131 & 9.310 & 3.380 & 0.001 & 0.001 & 0.010 & 0.011 & 0.070 & 0.510 \\
2012 & 0.220 & 0.011 & 14.430 & 0.790 & 0.004 & 0.010 & 0.010 & 0.010 & 0.090 & 1.820 \\
2013 & 0.201 & 0.131 & 12.140 & 0.732 & 0.001 & 0.011 & 0.245 & 0.210 & 0.135 & 2.921 \\
2014 & 0.060 & 0.020 & 15.300 & 0.788 & 0.026 & 0.089 & 0.247 & 0.289 & 0.142 & 3.013 \\
2015 & 0.050 & 0.010 & 13.450 & 2.030 & 0.000 & 0.020 & 0.011 & 0.010 & 0.070 & 1.560 \\
2016 & 0.040 & 0.010 & 11.240 & 1.150 & 0.010 & 0.010 & 0.090 & 0.010 & 0.040 & 1.090 \\
2017 & 0.045 & 0.066 & 14.117 & 3.034 & 0.003 & 0.009 & 0.081 & 0.062 & 0.01 & 0.295
\end{tabular}

Data source: Calculated based on data from the Mongolian National Bureau of Statistics.

Table 4 shows that in primary products (sitc0-4): The net trade ratio of China's exports in SITC2, SITC3 and SITC4 products is negative, indicating that non-edible raw materials, fossil fuels and lubricants, raw materials and animal fats are the least competitive.

Technology and capital products (SITC5, 7): the net trade ratio in SITC5 and SITC7 products includes negative Numbers, so China's exports of chemicals and machinery and transport equipment are less competitive. China's trade competitiveness in SITC 6 and SITC 8 products is relatively high, especially the net trade ratio of SITC 8 products is more than 0.5 , which indicates that China has the strongest competitiveness in the export of miscellaneous products. The net export trade ratio of SITC1, SITC5, SITC7 and SITC9 products is increasing year by year, and their competitiveness is gradually increasing. Due to the impact of the 2008 financial crisis, the net trade ratio of all kinds of products in China is negative, and only SITC6, SITC7 and SITC8 products with competitive advantages have relatively small trade influence.

Table 5 shows that the primary products (SITC0-4) : Mongolia in SITC0, SITC1, SITC3, net trade than SITC4 products export is negative, the food and live animals products, drink and smoke, fossil fuel and lubricating oil and raw materials, the weakest animal fat product competitiveness, but in most SITC2 is greater than 0.5, the Mongolia in non-food raw materials products, the strongest export competitiveness. Technology and capital intensive products (SITC5, 7) : the net trade ratio of SITC5 and SITC7 products was negative, and Mongolia's exports of chemicals and machinery and transport equipment were also the least competitive. Mongolia's trade competitiveness in SITC 6 and SITC 8 products was also weak, but the net trade of SITC 8 products showed a trend of decline since 2007. 
Table 4. Indicators of China's Net Trade Ratio

\begin{tabular}{|c|c|c|c|c|c|c|c|c|c|c|}
\hline Year & SITC 0 & SITC1 & SITC2 & SITC3 & SITC4 & SITC5 & SITC6 & SITC7 & SITC8 & SITC9 \\
\hline 2000 & 0.44 & 0.34 & 0.64 & 0.45 & 0.78 & 0.43 & 0.01 & 0.05 & 0.74 & 0.76 \\
\hline 2001 & 0.44 & 0.36 & 0.68 & 0.35 & 0.75 & 0.41 & 0.02 & 0.06 & 0.71 & 0.48 \\
\hline 2002 & 0.47 & 0.44 & 0.68 & 0.39 & 0.89 & 0.43 & 0.04 & 0.03 & 0.67 & 0.41 \\
\hline 2003 & 0.49 & 0.40 & 0.74 & 0.45 & 0.93 & 0.42 & 0.04 & 0.01 & 0.58 & 0.15 \\
\hline 2004 & 0.67 & 0.50 & 0.70 & 0.65 & 0.93 & 0.24 & 0.22 & 0.03 & 0.55 & 0.52 \\
\hline 2005 & 0.68 & 0.33 & 0.71 & 0.68 & 0.85 & 0.17 & 0.24 & 0.09 & 0.56 & 0.43 \\
\hline 2006 & 0.69 & 0.07 & 0.72 & 0.75 & 0.84 & 0.12 & 0.34 & 0.12 & 0.57 & 0.31 \\
\hline 2007 & 0.47 & 0.43 & 0.68 & 0.39 & 0.89 & 0.43 & 0.04 & 0.04 & 0.67 & 0.41 \\
\hline 2008 & 0.49 & 0.35 & 0.74 & 0.45 & 0.93 & 0.43 & 0.41 & 0.01 & 0.59 & 0.14 \\
\hline 2009 & 0.35 & 0.38 & 0.81 & 0.54 & 0.93 & 0.43 & 0.15 & 0.03 & 0.51 & 0.16 \\
\hline 2010 & 0.41 & 0.21 & 0.81 & 0.57 & 0.85 & 0.37 & 0.13 & 0.10 & 0.52 & 0.11 \\
\hline 2011 & 0.44 & 0.07 & 0.83 & 0.67 & 0.83 & 0.32 & 0.18 & 0.12 & 0.54 & 0.07 \\
\hline 2012 & 0.46 & 0.01 & 0.86 & 0.67 & 0.92 & 0.28 & 0.34 & 0.17 & 0.56 & 0.06 \\
\hline 2013 & 0.41 & 0.11 & 0.89 & 0.68 & 0.89 & 0.20 & 0.36 & 0.21 & 0.55 & 0.05 \\
\hline 2014 & 0.37 & 0.09 & 0.87 & 0.72 & 0.92 & 0.29 & 0.42 & 0.18 & 0.56 & 0.55 \\
\hline 2015 & 0.34 & 0.12 & 0.90 & 0.83 & 0.92 & 0.26 & 0.26 & 0.17 & 0.54 & 0.85 \\
\hline 2016 & 0.27 & 0.24 & 0.90 & 0.79 & 0.91 & 0.22 & 0.36 & 0.18 & 0.57 & 0.91 \\
\hline 2017 & 0.07 & 0.34 & 0.89 & 0.75 & 0.81 & 0.16 & 0.46 & 0.91 & 0.61 & 0.84 \\
\hline
\end{tabular}

Data source: Calculated based on data from the China bureau of statistics.

Table 5. Indicators of Mongolia's Net Trade Ratio

\begin{tabular}{c|llllllllll} 
Year & SITCO & SITC1 & SITC2 & SITC3 & SITC4 & SITC5 & SITC6 & SITC7 & SITC8 & SITC9 \\
\hline 2000 & 0.71 & 0.89 & 0.24 & 0.99 & 0.98 & 0.99 & 0.18 & 0.97 & 0.41 & 0.97 \\
2001 & 0.60 & 0.96 & 0.18 & 0.99 & 0.99 & 0.83 & 0.15 & 0.84 & 0.41 & 0.98 \\
2002 & 0.65 & 0.91 & 0.61 & 0.99 & 0.99 & 0.98 & 0.41 & 0.94 & 0.50 & 0.99 \\
2003 & 0.71 & 0.93 & 0.65 & 0.99 & 0.91 & 0.98 & 0.31 & 0.95 & 0.44 & 0.99 \\
2004 & 0.09 & 0.92 & 0.73 & 0.99 & 0.99 & 0.96 & 0.51 & 0.98 & 0.46 & 0.99 \\
2005 & 0.83 & 0.93 & 0.76 & 0.99 & 0.98 & 0.95 & 0.32 & 0.95 & 0.85 & 0.99 \\
2006 & 0.71 & 0.96 & 0.89 & 0.71 & 0.99 & 0.96 & 0.15 & 0.92 & 0.84 & 0.99 \\
2007 & 0.80 & 0.97 & 0.77 & 0.65 & 0.99 & 0.95 & 0.12 & 0.85 & 0.76 & 0.99 \\
2008 & 0.87 & 0.99 & 0.76 & 0.53 & 0.99 & 0.78 & 0.13 & 0.85 & 0.67 & 1.00 \\
2009 & 0.75 & 0.99 & 0.72 & 0.13 & 0.77 & 0.98 & 0.20 & 0.82 & 0.74 & 0.99 \\
2010 & 0.71 & 0.96 & 0.92 & 0.33 & 0.74 & 0.99 & 0.24 & 0.92 & 0.75 & 0.81 \\
2011 & 0.90 & 0.95 & 0.66 & 0.33 & 0.99 & 0.98 & 0.21 & 0.96 & 0.79 & 0.83 \\
2012 & 0.97 & 0.99 & 0.59 & 0.68 & 0.99 & 0.98 & 0.61 & 0.96 & 0.88 & 0.97 \\
2013 & 0.97 & 0.99 & 0.75 & 0.34 & 1.00 & 0.98 & 0.75 & 0.72 & 0.75 & 0.86 \\
2014 & 0.96 & 0.96 & 0.79 & 0.52 & 1.00 & 0.96 & 0.62 & 0.69 & 0.84 & 0.94 \\
2015 & 0.93 & 0.88 & 0.90 & 0.59 & 0.99 & 0.96 & 0.60 & 0.27 & 0.82 & 0.73 \\
2016 & 0.95 & 0.90 & 0.78 & 0.81 & 1.00 & 0.88 & 0.20 & 0.10 & 0.74 & 0.90 \\
2017 & 0.89 & 0.15 & 0.87 & 0.66 & 0.74 & 0.97 & 0.65 & 0.48 & 0.92 & 0.99
\end{tabular}

Data source: Calculated based on data from the Mongolian National Bureau of Statistics.

The complementary products of China and Mongolia are non-edible raw materials, finished products classified according to raw materials, machinery and transportation equipment, and special products. The competitive products of China and Mongolia are miscellaneous products. The inferior 
products of China and Mongolia are food and live animal products, beverage and tobacco, fossil fuel and lubricating oil, raw materials and chemical products.

Conclusions. The connection between the "One Belt and One Road" and the "Road to the Grasslands" proves that China and Mongolia economic and trade cooperation has reached a new stage of development, and trade and investment between the two countries are growing steadily. Through the calculation and analysis of the trade competitiveness and complementarity between China and Mongolia, it is found that the trade competitiveness between China and Mongolia is weak, while the trade potential between China and Mongolia is great.

According to the analysis of the integration degree of trade between China and Mongolia, China and Mongolia have close cooperation in trade, and Mongolia's high dependence on China for exports means that there is a large space for the development of trade between China and Mongolia. The docking of "One Belt and One Road" and "Grassland Road" initiative will surely provide more opportunities for the economic and trade cooperation between the two countries.

The explicit comparative advantage index and the net trade ratio index show that China has a competitive advantage in the export of manufactured goods, machinery and transportation equipment, and miscellaneous products classified by raw materials. Mongolia should continue to maintain the consumption of raw materials and special product competitive advantage, to achieve competitive advantage and drive the competitive disadvantage products, utilization of nature resources advantages, gradually fossil fuel and lubricating oil and raw materials exports at the same time, the introduction of foreign advanced science and technology, the fine chemical products, technology product innovation need to gradually turn competitive disadvantage.

China should make full use of its geographical advantages and remarkable achievements of reform and opening-up over the years, active play to the role of coordination and impeller in the northeast Asia cooperation, to promote the China and Russia economic corridor, as "China and Russia fate community" and "One Belt And One Road" with China the construction of a new type of regional cooperation mode endowed with new connotation, new basis, provide the momentum and cooperation framework.

\section{REFERENCES}

1. N. Otgonsaikhan. "Opportunities and conditions before the establishment of a joint cross-border free trade zone between Mongolia and China" [J]. Business school of Mongolian National University, 2018/1 (108):62-63

2. Wang Ling. "Analysis of comparative advantage and trade complementarity of agricultural products between China and major east Asian countries" [J]. School of business, Yangtze university, 2014 (2):76-77

3. Jie Lv and Long Bing Xiang, "An empirical analysis of bilateral trade complementarity between China and the United States" [J]. International Conference, 2010

4. Yang Cheng Jia and He Ji Ye. "The competitiveness and complementarity of trade cooperation between China and countries along the" One Belt and One Road "[J]. Northwestern university, 2018:51-52

5. Kabiru Hannafi Ibrahim. "Trade complementarity and similarity between they were and India in the context of as Trade relations" [J]. IOSR Journal of Economics and Finance (IOSR - their), 6 (6), 2015-28-32

6. Pan Yun Jiao. "Empirical analysis and potential measurement of bilateral trade between China and Mongolia" [J]. Jinan university, 2016:35-36

7. Diao Li, Shi Xin Xing, Luo Pei. "The economic structure complementarity of China, Russia and Mongolia and the construction of the free trade area of the three countries" [J]. 2015:16-21

8. Hou Wan Huan. "Study on trade complementarity and competitiveness between China and Mongolia" [J]. Harbin university of commerce, 2017:27-32

9. Wu Ying Jing, Li Xue Feng and Wang Nan. "Study on grassland silk road and China-Mongolia-Russia trade cooperation" [J]. Hulunbuir college, Inner Mongolia, 2017 (5) :28-31

10. Bao Ming Qi. "Research on China-Mongolia regional economic cooperation [J]. Hulunbuir college, Inner Mongolia, 2016:155-166

11. Kan Kang Li. "China and India Trade Competition and Complementary: Analysis of the" Belt and Road "Background" [J]. School of economics, Jinan university, Modern Economy, 2018 (9) :1213-1227

12. Data sources: http://comtrade.un.org/data; www.1212.mn; http://www.stats.gov.cn; 